\title{
IMPROVING STUDENT LEARNING ACTIVITIES THROUGH STUDENT TEAM ACHIEVEMENT DIVISION LEARNING MODEL
}

\section{PENINGKATAN AKTIVITAS BELAJAR SISWA DENGAN MODEL PEMBELAJARAN STUDENT TEAM ACHIEVEMENT DIVISION}

\author{
Oleh: \\ Gitta Permata Widyani \\ Accounting Education Study Program Yogyakarta State University \\ gittapermata@gmail.com
}

Sukirno

Lecturer in Accounting Education Study Program Yogyakarta State University sukirno@uny.ac.id

\begin{abstract}
A good learning method is a part of the factors that the school manage to improve students activities in a class. A cooperative learning model is one of the learning models are often used by teachers in their teaching learning process. This research aims to improve student learning activities through the implementation of student team achievement divisions (STAD) learning model. This research is a Classroom Action Research conducted in two cycles involving 30 students of class XII Social 1 SMA N 1 Wonosari academic year 2018/2019. Data were collected with an observation and a documentation equipped with observation sheets, observation guidelines, and field notes. Analysis of the data used a qualitative and quantitative approach consisting of data processing, data presentation and drawing conclusions. The result shows that the Implementation of STAD learning model can improve Accounting Learning Activities of students Class XII Social 1 SMA N 1 Wonosari supported by an increase in average of learning activities score from 56,02\% (in cycle I) to $92,07 \%$ (cycle II). Results are discussed and recommendation are provided.
\end{abstract}

Keywords: Accounting Learning Activities, STAD

\begin{abstract}
Abstrak
Metode pembelajaran yang baik adalah bagian dari faktor-faktor yang dikelola sekolah untuk meningkatkan aktivitas siswa di kelas. Model pembelajaran kooperatif adalah salah satu model pembelajaran yang sering digunakan oleh guru dalam proses belajar mengajar mereka. Penelitian ini bertujuan untuk meningkatkan aktivitas belajar siswa melalui model pembelajaran prestasi belajar siswa (STAD). Penelitian ini adalah Penelitian Tindakan Kelas yang dilaksanakan dalam dua siklus yang melibatkan 30 siswa kelas XII IPS 1 SMA N 1 Wonosari tahun ajaran 2018/2019. Data dikumpulkan dengan observasi dan dokumentasi yang dilengkapi dengan lembar observasi, pedoman observasi, dan catatan lapangan. Analisis data yang digunakan dalam pendekatan kualitatif dan kuantitatif terdiri dari pemrosesan data, penyajian data, dan penarikan kesimpulan. Hasil model pembelajaran STAD dapat meningkatkan Aktivitas Belajar Akuntansi siswa kelas XII IPS 1 SMA N 1 Wonosari dengan skor dari 56,02\% (pada siklus I) menjadi 92,07\% (siklus II). Hasilnya dibahas dan rekomendasi diberikan.
\end{abstract}

Kata Kunci: Aktivitas Belajar Akuntansi, STAD 


\section{INTRODUCTION}

Learning is one of the most important things that they do in school, where learning itself is an inseparable part of every human life. As explained by Priansa (2016: 53), learning is a process that is experienced by every individual during his life and also he said about learning that learning is a process of change in human personality as a result of experience or interaction between the individual and the environment (Priansa, 2016:55).

School is one of the facilities that can help students to carry out learning activities. Schools also do various things to facilitate their students to achieve optimal and useful learning when they are in school. One of the efforts is making innovation in learning methods. The cooperative learning model is one of the learning models that are often used by educators. In the context of teaching, Miftahul Huda (2012: 31) defines cooperative learning as the formation of small groups consisting of students who are required to work together and mutually enhance the learning of other students. The cooperative learning method is a learning method that emphasizes student activities by carrying the student-centered concept. This is in line with the statement of Isjoni (2007: 15) which says that Cooperative Learning is a learning model that is currently widely used to realize student-centered teaching and learning activities, especially those that address the problems found by teachers in activating students, who cannot work with other people, students who are aggressive and do not care for others. There are many types of cooperative learning models that can be used by teachers as an alternative in teaching one of which is the cooperative learning model of the Student TeamAchievement Division (STAD) type.

The cooperative learning model of the Student Team-Achievement Division (STAD) is a learning model that divides students into learning teams of 4-5 people who differ in their ability, gender, and ethnic background. Teachers deliver lessons, then students work on their teams to ensure that all team members have mastered the lesson. Furthermore, all students work on quizzes about the material individually, at which time they are not allowed to help each other (Slavin, 2016). While Mohamad Nur (2008: 5) said that in this model students are grouped in teams with 4 students on each team. Teams are formed heterogeneously according to the level of performance, gender, and ethnicity.

By implementing the cooperative learning model type STAD, class problems that usually run passively can be turned on with this learning model, students who are usually inactive asking questions and ashamed to express their opinions can participate in group discussions. The students who usually work in groups do not take part in working optimally or just rely on other group friends with this learning model that is required to have the same portion in the group. As well as students' boredom of accounting subjects will be reduced by using this learning method.

Based on preliminary observations conducted by researchers on Friday, March 2, 2018, on September 2018 and November 2018 in class XII of SMA 1 Wonosari there were several problems related to the method of learning carried out by the teacher. The lecture learning model adopted by teachers, in the majority were still teacher centered model so that students were passive, bored, and less motivated in participating in learning activities then, the student's learning outcomes were not optimal.

This could be seen when the initial observations, researchers got the results of observations as many as 17 out of 30 students or $56.67 \%$ of the total number of students, did not pay attention to the teacher while being explained Accounting material or someone who noticed but did nothing, such as recording, and talk to my peers who don't talk about Accounting material. While $43.33 \%$ can follow the learning process well 
when the teacher explains because they sit on a bench in a strategic position to listen to the teacher's explanation.

By looking at these conditions, it can be said that the learning activities of students in the class do not go accordingly. This is because these students do not carry out various activities that reflect learning activities. as According to Sardiman (2012: 100), learning activities are activities that are both physical and mental in nature, where both activities must be interrelated. Because with the connection between the two will create optimal learning activities. Activities in learning need to be done because in principle learning is doing. Doing to change behavior, so doing activities. There is no learning if there is no activity. That is why activity is a principle or principle that is very important in teaching and learning interactions (Sardiman, 2012: 95-96). Paul B. Diedrich in Sardiman (2012: 101) that there are 177 kinds of student learning activities that should occur in the classroom, whereof all kinds, will be classified into 8 groups of learning activities, namely, visual activities, oral activities, listening activities, writing activities, drawing activities, motor activities, mental activities, emotional activities.

Based on the components of the activity above, in the learning activities that the researchers observed, in the Accounting lesson, it can be seen that the activities carried out by $46.87 \%$ of the students above only carried out a portion of activities during learning. The researcher looked at the forms of activities students carried out in the interests of learning only seeing activities, listening activities, and writing activities. In part of the writing activity, it also does not work in accordance with the expected writing activity. Students will only write when the teacher gives the command to record or work on the task.

This is certainly not in line with the new curriculum concept, namely Curriculum 2013 wherein there are several directions related to Student Center learning activities. The curriculum 2013 is the development of the 2006 curriculum which was compiled in reference to the National Education Goals and based on previous curriculum evaluations in response to the challenges facing the nation in the future. Curriculum 2013 development, in particular, lies in the balance of knowledge - attitudes - skills, scientific approaches to learning, learning models (discovery, project-based, and problem-based), and authentic assessments. (Ministry of Education and Culture, March 2018).

Based on research conducted by Inayati (2015), she found that cooperative learning models Student Team Achievement Divisions (STAD) types can increase can increase Accounting Learning Activities of students of class AK 3 X Godean Vocational School 2014/2015 Academic Year as evidenced by an increase in Accounting Learning Activities from cycle I to cycle II in $15,97 \%$.

In addition, in a study compiled by Purwanti (2014), she found that Cooperative Learning Model Type Student Teams Achievement Divisions (STAD) can increase Accounting Learning Activities for Students of Class X Accounting 2 in SMK Negeri 1 Yogyakarta Academic Year 2013/2014. This increase is known from the percentage of the Accounting Learning Activity score of $55.17 \%$ from before Implementation of the Cooperative Learning Model Student Teams Achievement Divisions (STAD) increased to $71.03 \%$ in cycle I. Furthermore, from cycle I to cycle II there was an increase of $18,11 \%$ or a score of $89.14 \%$. Based on previous discussion this research aims to improve student learning activities through the implementation of student team achievement divisions (STAD) learning model. 


\section{RESEARCH METHOD}

The design of this study is classroom action research. This research was conducted collaboratively and participatively, meaning that researchers conducted research collaborating or collaborating with accounting teachers at SMA N 1 Wonosari. Sanjaya (2012: 26) defines classroom action research (CAR) as a process of reviewing learning problems in the classroom through self-reflection activities in an effort to solve these problems by doing various planned actions in real situations and analyzing each influence of treatment.

The subjects in this study were all students of class XII Social 1 SMA N 1 Wonosari Academic Year 2018/2019, while the objects in this study were Student Learning Activities in Accounting learning through the Implementation of Cooperative Learning Models Type Student Team Achievement Divisions (STAD).

This CAR procedure includes 2 cycles with the following stages. First is planning stage.Teacher prepared a Lesson Plan (RPP) regarding the learning materials of the Subsidiary Ledger for trading companies by applying the Cooperative Learning Model Type Student Team Achievement Divisions. After that prepared the subject matter to be taught. Then made an observation sheet to measured student activities along with observation guidelines. Prepared discussion tasks, quiz questions, along with the answer key. The last is made groups of 4-5 heterogeneous students.

Second is acting or action stage. In this stage start with the teacher gave greetings to students then checked the attendance of students and reviewed the previous subject matter, continues to provide perceptions relating to the Subsidiary Ledger. After that the teacher explained the learning objectives and introduced observers who will examine students' accounting learning activities. The teacher conveyed learning objectives and an overview of the cooperative learning model of the student team achievement division and next divided students in small groups of 4-5 students heterogeneously. In discussion stage students carried out a conceptual understanding of the material that the teacher has briefly presented before. Next, students are given individual tests or quizzes and group friends cannot help each other. The last is the teacher gives conclusions on the material that has been studied.

Next is observing or observation stage. This observation is done by observing various activities in the classroom such as the classroom atmosphere, classroom management by the teacher, how many students attended, and the obstacles faced in implementing the learning model.

The last is reflecting or reflection stage. At this stage an evaluation is carried out regarding the implementation of actions that have been carried out based on observations and interviews with students and teachers. This is done to find out the advantages and disadvantages of implementing learning activities.

After the first cycle is completed, the researcher and teacher then proceed to cycle II. The stages carried out in cycle II are the same as the stages in the first cycle, namely planning, acting, observing and reflecting. In cycle II aims to improve and improve the implementation of learning in the first cycle to achieve success.

The data collection technique in this research are observation and documentation.

The observation was done by observing and recording in the implementation of learning in the classroom and the participation shown by students when the teaching and learning activities take place. The observation was carried out using the student observation sheet that has been prepared.

While the documentation in this study is manifested in the form of photos of student activities while in class and syllabus for preparing Lesson Plan (RPP). 


\section{Research Instruments}

1. Observation Sheet

The Observation Sheet is used as a guideline for making observations indicated to obtain data on student learning activities in Accounting Subjects. Observations were carried out by 3 observers who made observations during the classroom learning guided by the observation guidelines prepared by the researcher. Accounting Learning Activity Indicators, modification of Paul B. Diedrich in Sardiman (2009: 101) to be examined are students pay attention to the explanations delivered by the teacher, students read the subject matter, students give questions about the material, students answer teacher's questions, students give their opinions during the discussion, students work on groups assignments given by the teacher, students work on quizzes individually, students record material that the teacher delivered.

2. Field Notes

Field notes in the form of forms used as note takers of the implementation of learning with cooperative learning models Student Team Achievement Division (STAD) type. Field notes are used to write down various events that occur in the classroom.

\section{Data Analysis Technique}

1. Processing Accounting Learning Activity Scores

a. Determine the scoring criteria for each indicator of the Accounting Learning Activity observed.

b. Calculating and add up the scores of all indicators of Accounting Learning Activities obtained by each student.

c. Calculating and summing the scores of all indicators of Accounting Learning Activities obtained by each student. d. Calculating the percentage score for each indicator of Accounting Learning Activity observed using the following formula:

$\frac{\text { Total Score for Each Indicator }}{\text { Maximal Score }} \times 100 \%$

e. Calculating the percentage of the Accounting Learning Activity score obtained by each student using the following formula: $\frac{\text { Total Score for Each Aspect }}{\text { Maximal Score }} \times 100 \%$

f. Calculating the percentage of average Learning Activities Accounting for students using the formula:

$\frac{\text { Total Score Student Activity }}{\text { Total of Indicator }} \times 100 \%$

(Sugiyono, 2015: 143-144)

2. Presenting Data

After data on Accounting Learning Activities were processed, the data was conveyed simply and presented in the form of tables and graphs so that it was easy to understand.

3. Drawing a Conclusion

This conclusion aims to answered the problem formulation that has been presented at the beginning of the study. After the data was presented in the form of tables and graphs, the data is then interpreted in a statement.

\section{Criteria of Successful}

The criteria for success of this study is an Improve in student learning activities in Accounting learning for students of class XII Social 1 SMA N 1 Wonosari during the learning process. Mulyasa (2009: 218) explains that in terms of processes, learning is said to be successful and quality if all or at least most $(75 \%)$ students are actively involved, both physically, mentally, and socially in the learning process. Referring to the statement, in this study the results of the study will be considered successful if they have achieved an average score of student learning activities of at least $75 \%$. The standard is also designed by referring to the Minister of Education and Culture Regulation No. 22 of 2016 concerning 
Standards for the Process of Primary and Secondary Education that the Learning Process in educational units is held in an interactive, inspirational, fun, challenging, motivating audience to actively participate.

\section{RESULT AND DISCUSSION Research Result Cycle I}

The learning process of account receivable and account payable subsidiary ledger in the first cycle was held on Tuesday, January 15, 2019 for one meeting (2 hours (a 45 minutes) from 08.45-09.30 after that break in 15 minutes and continue at 09.4510.30 WIB, but due to class agreement then the break gave after the accounting lesson was done, so the learning was over at 10:15 WIB.

a. Observation Data

Table 1. Percentage of Accounting Learning Activities for Students in Class XII Social 1 in Cycle I

\begin{tabular}{|c|l|c|}
\hline No & $\begin{array}{l}\text { Indicator of Accounting } \\
\text { Learning Activities }\end{array}$ & $\begin{array}{c}\text { Percentage } \\
(\%)\end{array}$ \\
\hline 1 & $\begin{array}{l}\text { Students pay attention to } \\
\text { the explanations delivered } \\
\text { by the teacher }\end{array}$ & 77,78 \\
\hline 2 & $\begin{array}{l}\text { Students read the subject } \\
\text { matter }\end{array}$ & 46,30 \\
\hline 3 & $\begin{array}{l}\text { Students give questions } \\
\text { about teaching and } \\
\text { learning activities about } \\
\text { the material }\end{array}$ & 38,89 \\
\hline 4 & $\begin{array}{l}\text { Students answer questions } \\
\text { asked by the teacher }\end{array}$ & 42,59 \\
\hline 5 & $\begin{array}{l}\text { Students give their } \\
\text { opinions during the } \\
\text { discussion }\end{array}$ & 68,52 \\
\hline 6 & $\begin{array}{l}\text { Students work on groups } \\
\text { assignments given by the } \\
\text { teacher }\end{array}$ & 64,81 \\
\hline 7 & $\begin{array}{l}\text { Students work on quizzes } \\
\text { individually }\end{array}$ & 72,22 \\
\hline 8 & $\begin{array}{l}\text { Students record material or } \\
\text { questions that the teacher } \\
\text { delivered }\end{array}$ & 37,04 \\
\hline \multicolumn{2}{|l|}{ Percentage Average } & 56,02 \\
\hline
\end{tabular}

Source: Primary Data Processed
The table above shows that the indicator read the subject matter at $46,30 \%$; asks about the material at $38.89 \%$; answer the questions posed by the teacher at $42.59 \%$; express opinions when the discussion is $68.52 \%$; working on group assignments given by the teacher is $64.81 \%$; working on individual quizzes at $72.22 \%$, and recording material or questions submitted by the teacher by $37.04 \%$ have not met the minimum criteria of $75 \%$.

b. Reflection

Implementation of Cooperative Learning Model Type STAD Type to Improve Accounting Learning Activities Students in Class XII Social 1 in the first cycle have not been implemented optimally. This is caused by several disadvantages, there are sttudents have not maximized the opportunity to ask questions or answer questions to the teacher when the teacher gives an explanation of the material. When in groups working on discussion questions some students have the ability and learning activities that are both busy working on their own questions and do not care about other students while students who have low learning activities tend to do activities outside the discussion, so that discussion activities do not run optimally. And while working on the quiz, some students seemed to lack confidence to work on their own so the quiz results did not reflect the actual abilities of students, even though the progress scores of each student would be the basis for calculating awards. The problems above can be solved by teachers should increase opportunities for students to ask and answer questions with a slight increase the duration of time the material explanation. Second, the teacher gives understanding to 
students that in discussing each group member must take part in the work of the group assignment, because everyone will be assessed for their learning activities and the results of the quiz will be the points of the group itself and teacher should provide understanding and emphasize to students to be honest in the quiz.

\section{Research Result Cycle II}

The learning process of Inventory Subsidiary Ledger in the second cycle is held on Wednesday, January 16, 2019 for one meeting ( 2 hours @ 45 minutes) from 12:3014.00 WIB.

a. Observation Data

Table 2. Percentage of Accounting Learning Activities for Students in Class XII Social 1 in Cycle II

\begin{tabular}{|c|l|c|}
\hline No & \multicolumn{1}{|c|}{$\begin{array}{c}\text { Indicator of } \\
\text { Accounting Learning } \\
\text { Activities }\end{array}$} & $\begin{array}{c}\text { Percentage } \\
(\%)\end{array}$ \\
\hline 1 & $\begin{array}{l}\text { Students pay attention to } \\
\text { explanations } \\
\text { delivered by the teacher }\end{array}$ & 86,54 \\
\hline 2 & $\begin{array}{l}\text { Students read the subject } \\
\text { matter }\end{array}$ & 92,31 \\
\hline 3 & $\begin{array}{l}\text { Students give questions } \\
\text { about teaching and } \\
\text { learning activities about } \\
\text { the material }\end{array}$ & 90,38 \\
\hline 4 & $\begin{array}{l}\text { Students answer } \\
\text { questions asked by the } \\
\text { teacher }\end{array}$ & 82,69 \\
\hline 5 & $\begin{array}{l}\text { Students give their } \\
\text { opinions during the } \\
\text { discussion }\end{array}$ & 98,08 \\
\hline 6 & $\begin{array}{l}\text { Students work on groups } \\
\text { assignments given by } \\
\text { the teacher }\end{array}$ & 100 \\
\hline 7 & $\begin{array}{l}\text { Students work on } \\
\text { quizzes individually }\end{array}$ & 92,31 \\
\hline 8 & $\begin{array}{l}\text { Students record material } \\
\text { or questions that the } \\
\text { teacher delivered }\end{array}$ & 94,23 \\
\hline & $\begin{array}{l}\text { Percentage Average } \\
\text { and }\end{array}$ \\
\hline
\end{tabular}

Source: Primary Data Processed

Accounting Learning Activity Table Class XII Social 1 Cycle II students have shown satisfactory results with the achievement of each indicator more than $75 \%$ and there is 1 indicator that reaches a percentage of $100 \%$, namely indicators working on group assignments given by the teacher. Learning Activities Accounting students increase because students realize to obtain maximum learning outcomes that can be seen from the quiz score where

Students are required to actively follow the course of the learning process with the Cooperative Learning Model Type STAD so that learning objectives will be achieved.

b. Reflection

The result is that there are no significant obstacles and overall the second cycle runs well and smoothly. Implementation of the Cooperative Learning Model The Student Team Achievement Division has improved the Accounting Learning Activity of students as shown by the increase in cycle I to cycle II. In addition, by using this method students' understanding increases in learning the material given by the teacher, namely the Helper Book material. This is indicated by the results of the increase in student grades from the quiz scores in cycle I and cycle II. From the results described above, it can be concluded that the implementation of classroom actions using the Cooperative Learning Model Type Student Team Achievement Division Division is generally considered to be successful in improving Accounting Learning Activities for students of class XII Social 1. 


\section{DISCUSSION}

Implementation of the Cooperative Learning Model The STAD type that is applied to Accounting subjects is done in 2 cycles with the stages of planning, implementing actions, observing and reflecting. The Cooperative Learning Model Type STAD aims to improve Accounting Learning Activities of students in class XII Social 1. The following table increases the indicator of Accounting Learning Activities of students of class XII Social 1 from cycle I to cycle II:

Table 3. Increased Accounting Learning Activity of Students from Cycle I to Cycle II.

\begin{tabular}{|c|c|c|c|c|}
\hline \multirow[t]{2}{*}{ No } & \multirow{2}{*}{$\begin{array}{l}\text { Accounting } \\
\text { Learning } \\
\text { Activity } \\
\text { Indicators }\end{array}$} & \multicolumn{2}{|c|}{ Cycle } & \multirow{2}{*}{$\begin{array}{c}\text { The In- } \\
\text { crease } \\
\text { (I-II) }\end{array}$} \\
\hline & & I & II & \\
\hline 1 & $\begin{array}{l}\text { Students } \\
\text { pay } \\
\text { attention to } \\
\text { the explana- } \\
\text { tions } \\
\text { delivered by } \\
\text { the teacher }\end{array}$ & $\begin{array}{c}77,7 \\
8 \%\end{array}$ & $\begin{array}{c}86,5 \\
4 \%\end{array}$ & $8,76 \%$ \\
\hline 2 & $\begin{array}{l}\text { Students } \\
\text { read the } \\
\text { subject } \\
\text { matter }\end{array}$ & $\begin{array}{c}46.3 \\
0 \%\end{array}$ & $\begin{array}{c}92.3 \\
1 \%\end{array}$ & $46.01 \%$ \\
\hline 3 & $\begin{array}{l}\text { Students } \\
\text { give } \\
\text { questions } \\
\text { about } \\
\text { learning } \\
\text { activities } \\
\text { about the } \\
\text { material }\end{array}$ & $\begin{array}{c}38,8 \\
9 \%\end{array}$ & $\begin{array}{c}90,3 \\
8 \%\end{array}$ & $51,49 \%$ \\
\hline 4 & $\begin{array}{l}\text { Students } \\
\text { answer } \\
\text { questions } \\
\text { asked by the } \\
\text { teacher }\end{array}$ & $\begin{array}{c}42,5 \\
9 \%\end{array}$ & $\begin{array}{c}82,6 \\
9 \%\end{array}$ & $40,10 \%$ \\
\hline 5 & $\begin{array}{l}\text { Students } \\
\text { give their } \\
\text { opinions }\end{array}$ & $\begin{array}{l}68,5 \\
2 \%\end{array}$ & $\begin{array}{c}98,0 \\
8 \%\end{array}$ & $29,56 \%$ \\
\hline
\end{tabular}

\begin{tabular}{|c|c|c|c|c|}
\hline \multirow[t]{2}{*}{ No } & \multirow{2}{*}{$\begin{array}{l}\text { Accounting } \\
\text { Learning } \\
\text { Activity } \\
\text { Indicators }\end{array}$} & \multicolumn{2}{|c|}{ Cycle } & \multirow{2}{*}{$\begin{array}{l}\text { The In- } \\
\text { crease } \\
\text { (I-II) }\end{array}$} \\
\hline & & $\mathbf{I}$ & II & \\
\hline & $\begin{array}{l}\text { during the } \\
\text { discussion }\end{array}$ & & & \\
\hline 6 & $\begin{array}{l}\text { Students } \\
\text { work on } \\
\text { groups } \\
\text { assignments } \\
\text { given by the } \\
\text { teacher }\end{array}$ & $\begin{array}{c}64,8 \\
1 \%\end{array}$ & $\begin{array}{c}100 \\
\%\end{array}$ & $35,19 \%$ \\
\hline 7 & $\begin{array}{l}\text { Students } \\
\text { work on } \\
\text { quizzes } \\
\text { individually }\end{array}$ & $\begin{array}{l}72,2 \\
2 \%\end{array}$ & $\begin{array}{c}92,3 \\
1 \%\end{array}$ & $20,09 \%$ \\
\hline 8 & $\begin{array}{l}\text { Students } \\
\text { record } \\
\text { material or } \\
\text { questions } \\
\text { that the } \\
\text { teacher } \\
\text { delivered }\end{array}$ & $\begin{array}{l}37,0 \\
4 \%\end{array}$ & $\begin{array}{l}94,2 \\
3 \%\end{array}$ & $57,19 \%$ \\
\hline & $\begin{array}{l}\text { rage Score of } \\
\text { Accounting } \\
\text { Learning } \\
\text { Activities }\end{array}$ & $\begin{array}{l}56.0 \\
2 \%\end{array}$ & $\begin{array}{l}92.0 \\
7 \%\end{array}$ & $36.05 \%$ \\
\hline
\end{tabular}

Source: Primary Data Processed

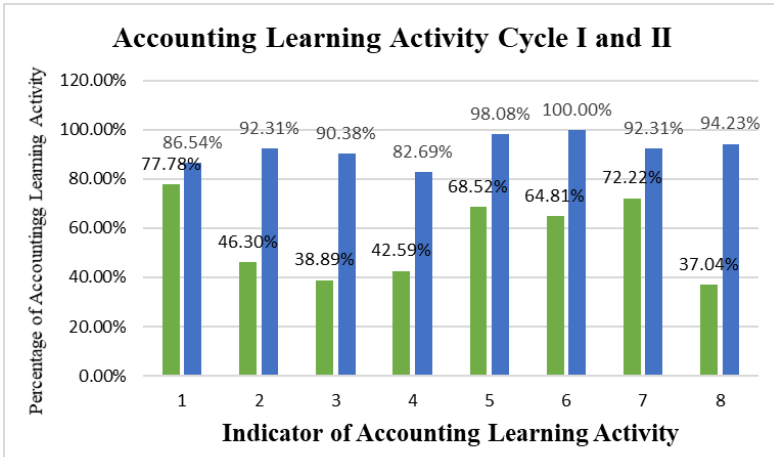

Figure 1. Percentage of Accounting Learning Activity Increase in Cycle I and II

Information:

1 : Pay attention to the explanation conveyed by the teacher

2 : Read the subject matter

3 :Ask about material during the teaching and learning process 
4 : Answering questions asked by the teacher

5 : Express opinions during discussion

6 : Work on group assignments given by the teacher

7 : Work on individual quizzes

8 : Take notes on the material or questions the teacher presents

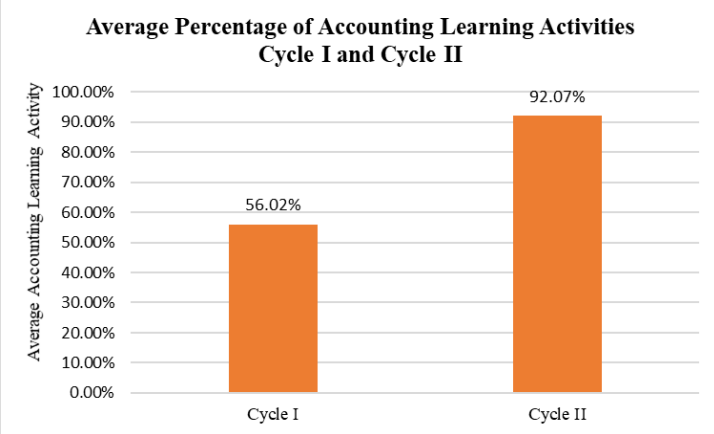

Figure 2. Average Percentage of Accounting Learning Activities Cycle I and Cycle II

Based on the data and diagrams above can be seen there has been an average increase in Accounting Learning Activities from the first cycle of $57.41 \%$ to $92.03 \%$ in the second cycle. The magnitude of the increase in cycle I to cycle II is $34.63 \%$. Accounting Learning Activity Data from cycle I to cycle II experienced an increase in each indicator. Indicators pay attention when the teacher explains an increase of $8.67 \%$, namely the first cycle of $77.78 \%$ to $86.54 \%$ in the second cycle. Indicators asking about the material during the teaching and learning process increased by $51.49 \%$, namely the first cycle $38.89 \%$ to $90.38 \%$ in the second cycle. Indicators answering questions raised by teachers have increased by $40.10 \%$, namely cycle I $42.59 \%$ to $82.69 \%$ in cycle II. Indicators of students express opinions when discussions increase $29.56 \%$, namely cycle I $68.52 \%$ to $98.08 \%$ in cycle II. Indicators working on group assignments given by teachers increased $35.19 \%$, namely cycle I $64.81 \%$ to $100 \%$. The indicator of working on individual quizzes increased by $20.09 \%$, namely cycle I $72.22 \%$ to $92.31 \%$ in cycle II. Indicators record the subject matter described has increased by $57.19 \%$, namely cycle I $37.04 \%$ to $94.23 \%$ in cycle II. The following are conclusions made by researchers based on each indicator of Accounting Learning Activity:

1. Indicators Pay Attention to the Explanations Presented by the Teacher.

In the first cycle obtained a percentage of $77.78 \%$ and the second cycle obtained a percentage of $86.54 \%$ and an increase of $8.76 \%$.

2. Indicator of read the subject matter

The increase in the percentage of accounting learning activities on this indicator amounted $46,01 \%$ from the cycle I of $46,30 \%$ to $92,31 \%$ in cycle II.

3. Indicators Asking About Material during the Teaching and Learning Process

Cycle I obtained a percentage of $38.89 \%$ and the second cycle obtained a percentage of $90.38 \%$ and an increase of $51.49 \%$.

4. Indicators of Answering Questions Asked by Teachers

In the first cycle obtained a percentage of $42.59 \%$ and in the second cycle obtained a percentage of 82.69 $\% \%$ and there has been an increase of $40.10 \%$.

5. Indicators Expressing Opinions during Discussion

In the first cycle obtained a percentage of $68.52 \%$ and the second cycle obtained a percentage of $98.08 \%$ and an increase of $29.56 \%$.

6. Indicator Working on the Task Group Given by the Teacher

In the first cycle obtained a percentage of $64.81 \%$ and the second cycle obtained a percentage of $100 \%$ and an increase of $35.19 \%$.

7. Indicator of Working Quiz Individually In the first cycle obtained a percentage of $72.22 \%$ and the second cycle obtained a percentage of $92.31 \%$ and an increase of $20.09 \%$. 
8. Indicators of Notes on Material or Questions Presented by the Teacher

In the first cycle obtained a percentage of $37.04 \%$ and in the second cycle obtained a percentage of $94.23 \%$ and an increase of $57.19 \%$.

From the 8 indicators outlined above, it can be seen that there is an increase in each indicator. Each indicator represents an overview of students' accounting learning activities that have increased after using the Student Team Achievement Division (STAD) Cooperative Learning Model. Increased Accounting Learning Activities increased from the beginning to the end of the learning process, especially during group discussions because students are required to be active in order to be able to follow the STAD Cooperative Learning Type flow. In addition, students also realize that increased learning activities will have an impact on the success of learning in the classroom.

Increase in activity on each of these indicators in accordance with expressed by Usman (2013: 26-27), he suggest one way to improve and enhance learning activities is to increase student participation actively in teaching and learning activities by demanding an active response from students and using various teaching techniques, motivation, and reinforcement. According to Nugroho, Hartono, S.S. Edi (2009: 112) the advantages of Cooperative Learning Model Type STAD i.e. students more easily understand the subject matter because they are already accustomed to learning in cooperative work in groups to solve any issues and Cooperative Learning Model Type STAD can create a sense of confidence in the students, the atmosphere of the pillars, sharing and responsibility.

The implementation of the STAD learning model is also in accordance with the curriculum concept 2013 that curriculum 2013 development in a balance of knowledge - skills, scientific approaches to learning, learning models (discovery, project-based and problem-based), and authentic assessments . (Ministry of Education and Culture, March 2018).

According to Isjoni (2010: 74) Cooperative Learning Model STAD type is one type of cooperative that emphasizes the existence of activities and interactions between students to motivate each other and help each other in mastering the subject matter in order to achieve maximum achievement. In addition, this study is also in line with research conducted by Nur Inayati and Ela Purwanti which shows an increase in Accounting Learning Activities by using the Student Team Achievement Divisions (STAD). Thus it can be concluded that the Cooperative Learning Model Type Student Team Achievement Divisions (STAD) can Improve Accounting Learning Activities of Class XII Social 1 Students of SMA N 1 Wonosari Academic Year 2018/2019.

\section{CONCLUSIONS AND SUGGESTIONS Conclusions}

Based on the results of the research and discussion in the previous chapter, it can be concluded that the Implementation of Cooperative Learning Model Type Student Team Achievement Division can Improve Accounting Learning Activities of students of class XII Social 1 SMA N 1 Wonosari Academic Year 2018/2019.

Increasing Accounting Learning Activities can be seen from the increase in the average score of Accounting Learning Activities from cycle I to cycle II and has reached the minimum specified criteria that is equal to $\geq 75 \%$. The percentage score of the average Accounting Learning Activity was $57.41 \%$ in the first cycle and $92.03 \%$ in the second cycle. An increase from cycle I to cycle II was $34.63 \%$.

\section{Suggestion}

Based on the results of the research and the conclusions obtained, then to increase the Accounting Learning Activity by applying the Cooperative Learning Model 
Type Student Team Achievement Division (STAD) is given some suggestions.

Accounting Teachers of SMA N 1 Wonosari need for innovation in the implementation of the learning process. The selection of learning methods must be adapted to the characteristics and abilities of students, so that teaching and learning can be carried out better.

The teacher can apply the Student Team Achievement Divisions Cooperative Learning Model to Improve Learning Activities Accounting students in other basic competencies so that student activity does not only increase when research.

Suggestions are also addressed to the students to be active in every classroom learning, activities carried out of course learning activities. The activeness of student learning activities during the learning process is very important to support maximum learning outcomes because if students are active in the classroom it will facilitate the absorption of the material explained by the teacher.

The last is for future researcher, there are the researchers are expected to be able to improve the aspects observed in learning activities so that they can show an increase in overall Accounting Learning Activities and can try to apply the Cooperative Learning Model Student Teams Condition Division (STAD) to improve Accounting Learning Activities in other Basic Competencies, so as to enrich the repertoire of knowledge in the field of education and help solve problems that exist in the field.

\section{REFERENCES}

Depdikbud. (2013). Undang-Undang RI No 20, Tahun 2013, tentang Sistem Pendidikan Nasional. Jakarta: Depdiknas
Huda, M. (2012). Cooperative Learning Metode, Teknik, Struktur dan Model Terapan. Yogyakarta: Pustaka Pelajar. Isjoni. (2007). Cooperatif Learning Efektifitas Pembelajaran Kelompok, Bandung: Alfabeta.

Mulyasa. (2011). Kurikulum Yang Disempurnakan. Bandung: PT Remaja Rosdakarya

Priansa, D.P. (2017). Pengembangan Strategi \& Model Pembelajaran. Bandung: CV Pustaka Setia

Sanjaya, W. (2012). Penelitian Tindakan Kelas. Jakarta: Kencana Prenada Media Group.

Sardiman A.M. (2012). Interaksi dan Motivasi Belajar Mengajar. Depok: PT. Rajagrafindo Persada.

Slavin, Robert E. (2010). Cooperative Learning. Bandung: Nusa Media.

Sugiyono. (2015). Metode Penelitian Pendidikan (Pendekatan Kuantitatif, Kualitatif dan $R \& D)$. Bandung: Alfabeta

U Nugroho, Hartono, S.S. Edi. (2009). Penerapan Pembelajaran Kooperatif Tipe STAD Berorientasi Keterampilan Proses. Accessed from: http://download.portalgaruda.org/artic le.php?article $=135364 \&$ val $=564 \&$ titl $\mathrm{e}=$ PENERAPAN\%20PEMBELAJAR AN\%20KOOPERATIF\%20TPE\%20 STAD\%20BERORIENTASI\%20KE TERAMPILAN\%20PROSES accessed on February, $5^{\text {th }} 2019$.

Usman, U. (2013). Menjadi Guru Profesional. Bandung: PT Remaja Rosdakarya. 